\title{
Impact of Depreciation Deduction Calculation Method on Financial Soundness Improvement of Economic Agents
}

\author{
Yurii V. Mishin ${ }^{1, *}$, and Aleksandr Yu. Mishin ${ }^{2}$ \\ ${ }^{1}$ State University of Management, 99, Ryazansky Prospekt, 109542 Moscow, Russian Federation \\ ${ }^{2}$ Financial University under the Government of the Russian Federation, 49, Leningradsky Prospekt, \\ 125993 Moscow, Russian Federation
}

\begin{abstract}
The purpose of this paper is to prepare suggestions on the use of capital depreciation methods as the key tool of industrial enterprise and organization financial soundness improvement that provides the gained profit increase, and thus the capital position. The paper solves the following issues: 1) In the result of comparative analysis of specific features, advantages and disadvantages of depreciation accrual methods, indices of average annual manufacturing capacity actual employment in the context of the most important types of output industrial products it was concluded that the majority of such methods (except the method for depreciation accrual in proportion to the gross output) doesn't consider the actual load of process equipment; 2) the methodological approach to modification of average annual manufacturing capacity actual employment was substantiated by introducing the calculation formula and the coefficient of average annual manufacturing capacity actual employment; 3) calculations on annual 2016 and 2017 returns were carried out for several economic activities in order to assess product cost reduction (growth of profits) due to the proposed methodological approach.
\end{abstract}

\section{Introduction}

Broadly, the enterprise stable functioning is determined by its composition and structure of its operation funding sources - the financial soundness. It is in relatively long-term perspective the most important financial solvency feature of any economic agents: enterprises, partnerships, limited liability companies and joint-stock companies, etc.

Mainly, the financial soundness level at algorithmic and logic level is determined by the amount of own capital, which main growth driver is the balance net profit in hands of the enterprise.

We think that the notable reserve for enterprise and organization financial soundness improvement can become the use of superior and objective methods for fixed assets depreciation determination. The fact of the matter is that currently, the fixed assets

\footnotetext{
*Corresponding author: myv1@rambler.ru
} 
accounting uses methods for depreciation calculation left since the earliest Soviet times that form artificial overvaluations of active fixed assets' use, the process equipment.

The reasonability of choosing the key optimization element is caused by its high share in manufacturing expenses. Thus, according to the Rosstat data for 2016 (more recent official statistical data have not available yet), the fixed assets depreciation share in product (goods, works, services) manufacturing expenses amounts to: in manufacturing industry: $3.9 \%$; in mineral extraction industry: $13.8 \%$; in agriculture: $8.1 \%$; electric energy, gas and water generation and distribution: $9.2 \%$; in transport and communication: $8.9 \%$; and in construction: $3.8 \%$.

The applied depreciation deduction calculation method directly impacts the depreciation amount. In case of increase, the taxable income decreases that initially leads to the growth of manufacturing expenses, product costs, as depreciation deductions are their components that further results in the corresponding taxable income decrease. It allows to decrease and defer to future periods assignments to budget and provide the possibility to acquire the additional funding sources.

Evaluating such approach from the financial soundness point of view, it is arguable that it will result in its decrease as the share of available profit in enterprise hands reduces and the financial soundness decreases. It is certain that the taxation optimization by selection of varying elements minimizing the gained profit share mainly solves only one issue for taxpayers - the legal tax avoidance.

\section{Materials and Methods}

Issues of economic agent financial soundness evaluation and management were deeply reflected in the following works of foreign [13] and Russian scientists: L.V. Davydova, N.Yu. Bazyuk, G.A. Kremsal, M.I. Bakanov, M.V. Melnik, A.D. Sheremet, F.E. Karaeva, P.N. Krasavina, etc. $[1,2,3,4,5]$. Conversely, the taxation optimization on the basis of accounting policy formation issue was studied the following scientists-accountants and financiers: V.V. Kovalev, B.K. Kushubaeva, E.Yu. Makeeva, Yu.M. Lermontov, E.L. Logvinov, A.N. Semenova, A.F. Myalkina and Z.S. Tuyakova [6, 7, 8, 9,10, 11]. Separate studies devoted to issues of accounting policy impact on financial soundness of enterprises and organisations were not conducted.

Generally, research methods were based on the systematic approach, the most important provisions, categories and parameters in sphere of economic analysis, corporate management theory, accounting and finance. In the course of analysis and preparation of suggestions on amendment of the linear depreciation deduction calculation method were use methods of analysis and synthesis, mathematical deduction and induction, grouping and comparison.

As the paper information base along with literature sources and the official Rosstat statistical reporting were also used statutory documents in sphere of accounting and taxation (Tax Code of the Russian Federation and approved by Ministry of Finance of the Russian Federation "Russian Fixed Assets Accounting Standards" (RAS 6.01.)").

In the estimation of most researchers, issues of financial soundness assessment, it can be determined on the basis of seven parameters: self-sufficiency, debt to equity ratio, financial dependence, investment reserve, working capital to current assets ratio, current assets to equity ratio, current assets to functioning capital ratio. For the calculation of majority of the most important and notable of them expressly or impliedly is used the equity and profit parameter. Provided that the bigger parameter value is, the bigger is the economic agent financial soundness. Thus, in order improve the financial soundness, it is required to choose such varying accounting policy elements that provide the maximum possible share of gained profit due to the product cost minimization - the reduction of depreciation deduction amounts. 


\section{Results and Discussion}

"Russian Fixed Assets Accounting Standards" (RAS 6.01.)" approved by the Order of Ministry of Finance of the Russian Federation dd. 30.03.2001 No. 26-H (revised on 16.05.2016) establish the main requirements to fixed assets (the use during long period - over 12 months, reselling prohibition, the perspective operation shall provide the economic benefit (profit)).

If they are carefully analysed, it appears that for any registered object notwithstanding is actual use in the manufacturing process, will be accrued depreciation deduction providing its $100 \%$ load during the accounting period.

In accordance with the applicable accounting guidance notes, the determination of depreciation deduction amount by fixed assets units is allowed to carry out by the four following methods: linear, nonlinear, declining balance method, sum-of-the-digits depreciation and service life in proportion to output (scope of works).

The determination of annual depreciation deduction amount using the simplest linear method is carried out by multiplication of the initial cost or (current replacement) cost (in case of revaluation) of fixed assets unit by constant value, the depreciation rate inverse to the unit useful service life.

The declining balance method being the modification of the first approach by is economic substance resides at the fact that the annual depreciation deduction amount shall be determined by multiplication of the opening depreciated value of fixed assets unit calculated on the basis of useful service life by depreciation rate and the coefficient established by the organization (max. 3).

The sum-of-the-digits methodological approach is in the multiplication on the basis of the initial cost or (current replacement) cost (in case of revaluation) of fixed assets unit by ratios, which numerator is the number of years remaining to the end of useful service life and the denominator is the aggregate of useful service life years.

And the last, the fourth method is the most accurate and complicated is the depreciation in proportion to output (scope of works). The depreciation deduction amount is calculated by multiplication the output (scope of works) in kind for the reporting period by the ratio of initial cost of fixed assets unit and the estimated output (scope of works) for the total useful service life. The core methodological issue is when the same unit is used for manufacturing of different products. The solution of this issue foresees the cooperation of accountants and design and process engineers.

The Federal Taxation Service made its contribution in the development of depreciation deduction calculation method by capturing in the Tax Code of the Russian Federation (Part II) adopted on August 05, 2000 as the Federal Law 117-FZ (updated on 22.04.2020) (Article 259) two main depreciation deduction calculation methods: linear and nonlinear. Linear methods of depreciation deduction for taxation purposes and accounting are identical

The nonlinear deduction method is in the discriminatory establishment of monthly depreciation rates for ten property groups. The assets grouping is carried out depending on their useful service life (from 1 year and over 30 years). The asset with the lowest useful service life (from 1 to 2 years, inclusively) has the highest depreciation rate: $14.3 \%$ and the asset with the highest useful service life (over 30 years) has the minimum value: $0.7 \%$.

The common method used for depreciation deduction calculation in accounting and fiscal accounting of fixed assets in the linear method. Essentially, under such conditions economic agents are forced to use them as the primary (only) asset in order not to cook the books.

In the centralized directive planning system production associations (plants), enterprises should have to fill the special accounting form $04 \Pi$ "Balance of Manufacturing Capacity Employment" in development of five-year and annual plans (Technical and Industrial Financial Plans). It consists of three main parts: capacity increase over the year, capacity 
decrease over the year and calculation of annual capacity employment parameters. The first group parameters are provided in the context of total value, including due to commissioning of shops and sections, implementation of organizational and technical measures, change of enterprise operation schedule, increase of equipment rotation and change of product range, decrease of labour intensity. The second group is represented by directions of capacity decrease within the planned period: aggregate and by key elements: change of product range (increase of labour intensity), change of operation schedule, decrease of rotation and retirement (decay, stock). The third group is represented by the closing capacity calculation in product range and assortment of the corresponding plan period, average annual capacity, product output or quantity of processed raw materials and average annual capacity employment coefficient. Coefficients of average annual employment calculated by the main product range in kind and in value shall be focused on the maximum possible product output upon the fullest use of facilities according to the established specialization and operation schedule.

For this reason, parameters of manufacturing potential employment were relatively high (app. $90-95 \%$ ) under such conditions the linear depreciation deduction calculation method has worked. However, at the moment the manufacturing capacity utilization depends on the effective demand for products.

For example, in 2018 the actual production manufacturing capacity utilization rate amounted to only $57.5 \%$. The highest manufacturing capacity utilization rate was observed in manufacturing industries (forest, wood-processing, pulp and paper): $80.0 \%$ (one product type has the rate from 30 to $50 \%$ and three product types $>70 \%$ ), petroleum and petrochemical industries: $76 \%$ (one product type has the rate from 30 to $50 \%$, two product types have the rate from 50 to $70 \&$ and six product types have $>70 \%$ ), mineral extraction: $62.1 \%$ (one product type has the rate from 30 to $50 \%$, two product types have the rate from 50 to $70 \&$ and six product types have $>70 \%$ )(Tables 1 and 2 ).

Table 1. Average annual manufacturing capacity employment level by major industry sector groups

\begin{tabular}{|c|c|c|c|}
\hline Name of major industry sectors & \multicolumn{3}{|c|}{ Average annual manufacturing capacity } \\
employment level \\
\cline { 2 - 4 } & 2017 & 2018 & $\begin{array}{c}\text { Growth rate } \\
\text { (in \% to } \\
2017)\end{array}$ \\
\hline 1. & & & 4. \\
\hline Total per industry sector, including & 57.5 & 57.8 & 100.5 \\
\hline Mineral Extraction & 61.5 & 62.1 & 101.0 \\
\hline Ferrous Metallurgy & 68.0 & 56.3 & 82.8 \\
\hline Dairy and Meat Industry - & 57.2 & 58.4 & 102.1 \\
\hline Food Industry - Total & 53.0 & 53.1 & 100.2 \\
\hline Consumer Industry & 41.7 & 45.4 & 108.9 \\
\hline $\begin{array}{c}\text { Forest, Wood-Processing, Pulp and } \\
\text { Paper Industry }\end{array}$ & 78.1 & 80.0 & 102.4 \\
\hline Machinery and Metal Working & 25.5 & 28.3 & 111.0 \\
\hline Industry & & & 100.0 \\
\hline Chemical and Petrochemical Industry & 76.0 & 76.0 & 98.8 \\
\hline Construction Materials & 56.3 & 55.6 & \\
\hline
\end{tabular}


Table 2. Grouping of major industry sectors depending on average annual manufacturing capacity employment in 2018

\begin{tabular}{|c|c|c|c|c|c|c|c|c|}
\hline \multirow{3}{*}{$\begin{array}{l}\text { Name of } \\
\text { major } \\
\text { industry } \\
\text { sectors }\end{array}$} & \multicolumn{8}{|c|}{ Average annual manufacturing capacity employment level in 2018} \\
\hline & \multicolumn{2}{|c|}{$10-30 \%$} & \multicolumn{2}{|c|}{$30-50 \%$} & \multicolumn{2}{|c|}{$50-70 \%$} & \multicolumn{2}{|c|}{$>70 \%$} \\
\hline & $\begin{array}{c}\text { Produc } \\
t \text { unit }\end{array}$ & $\begin{array}{c}\text { In } \% \text { of } \\
\text { total } \\
\text { quantit } \\
y\end{array}$ & $\begin{array}{c}\text { Produc } \\
t \text { unit }\end{array}$ & $\begin{array}{c}\text { In \% of } \\
\text { total } \\
\text { quantit } \\
y\end{array}$ & $\begin{array}{c}\text { Produc } \\
t \text { unit }\end{array}$ & $\begin{array}{c}\text { In } \% \text { of } \\
\text { total } \\
\text { quantit } \\
y\end{array}$ & $\begin{array}{c}\text { Produc } \\
t \text { unit }\end{array}$ & $\begin{array}{c}\text { In } \% \text { of } \\
\text { total } \\
\text { quantit } \\
y\end{array}$ \\
\hline 1. & 2. & 3. & 4. & 5. & 6. & 7. & 8. & 9. \\
\hline $\begin{array}{l}\text { Total per } \\
\text { industry } \\
\text { sector, } \\
\text { including }\end{array}$ & 12 & 18.8 & 16 & 20.5 & 18 & 28.1 & 18 & 28.1 \\
\hline $\begin{array}{c}\text { Mineral } \\
\text { Extraction }\end{array}$ & & & 1 & 1.6 & 1 & 1.55 & 1 & 1.6 \\
\hline $\begin{array}{c}\text { Ferrous } \\
\text { Metallurgy }\end{array}$ & 1 & 1.6 & 1 & 1.6 & 1 & 1.55: & 4 & 6.4 \\
\hline $\begin{array}{c}\text { Dairy and } \\
\text { Meat } \\
\text { Industry - }\end{array}$ & & & 2 & 3.2 & 5 & 8.0 & 1 & 1.6 \\
\hline $\begin{array}{c}\text { Food } \\
\text { Industry - } \\
\text { Total }\end{array}$ & & & & & & & & \\
\hline $\begin{array}{l}\text { Consumer } \\
\text { Industry }\end{array}$ & & & 4 & 6.25 & 5 & 8.0 & 1 & 1.6 \\
\hline $\begin{array}{l}\text { Forest, } \\
\text { Wood- } \\
\text { Processing, } \\
\text { Pulp and } \\
\text { Paper } \\
\text { Industry }\end{array}$ & & & & & 1 & 1.6 & 3 & \\
\hline $\begin{array}{c}\text { Machinery } \\
\text { and Metal } \\
\text { Working } \\
\text { Industry }\end{array}$ & 11 & 17.2 & 4 & 6.25 & & & & \\
\hline $\begin{array}{c}\text { Chemical } \\
\text { and } \\
\text { Petrochemica } \\
1 \text { Industry }\end{array}$ & & & 1 & 1.6 & 2 & 3.2 & 6 & 9.6 \\
\hline $\begin{array}{l}\text { Construction } \\
\text { Materials }\end{array}$ & & & 3 & 4.8 & 3 & 4.8 & 2 & 3.2 \\
\hline
\end{tabular}

The lowest level of manufacturing potential employment, $28.3 \%$ is recorded in machinery and metal working, which majority of products (eleven of fifteen) has the low manufacturing capacity utilization rate (within $10-30$ percent) and four products have the utilization rate from 30 to 50 percent.

For this reason, significant reserves for improvement of fixed industrial and manufacturing assets utilization efficiency due to the increase of average annual manufacturing capacity are primarily available in high-tech industry sectors: machinery and metal working, approximately 2.5 times higher (from $28.3 \%$ to $70.0 \%$ ), consumer industry 1.7 times higher (from 45.4 to $70 \%$.),

In order to account the actual use of the active fixed industrial and manufacturing assets (FIMA), primarily, during the determination of depreciation deductions using the linear method, the correction of values with the coefficient of actual average annual capacity use in the reporting year shall be carried out. 
The application of proposed modified methods for calculation of depreciation deductions will result in finished product cost reduction (the corresponding profit growth) (based on the planned level of $70 \%$ load of manufacturing capacity) within the Russian industry, but only in the group of industry sectors: mineral extraction industry: $1.6 \%(13.8 \%-[13.8$ $\div 70.0 \div 62.1]$ and machinery and metal working: $2.34 \%(3.9 \%-[3.9 \% \div 70.0 \div 28.3 \%]$.

\section{Conclusion}

The practical application of the proposed method of depreciation deduction calculation will provide the growth of objectivity and reliability of physical wear of fixed assets and manufacturing potential parameters; and the calculation of summarizing production efficiency indicators on its basis, first of all, the return of assets, finished product cost and profit. All that undoubtedly will ensure both own economic agent capital growth and their financial soundness.

\section{References}

1. L.V. Davydova, Enterprise Financial Soundness.Finance, Money Circulation and Credit don't reflect the reality in sphere of actual depreciation of industry fixed assets. The Thesis for a Doctor's of Economics Degree by Speciality 08.00.10. Finance

2. N.Yu. Bazyuk, G.A. Kremsal, Russian Entrepreneurship, 19 (241), 140 (2013)

3. M.I. Bakanov, M.V. Melnik, A.D. Sheremet, The Economic Analysis Theory. The fifth edition, 536 (2007)

4. F.E. Karaeva, Scientific Proceedings, 7 (2017)

5. P.N. Krasavina, Money and Credit, 5, 52 (2004)

6. V.V. Kovalev, Financial Analysis. Capital Management. Investment Selection, Report Analysis, 511 (1999)

7. B.K. Kushubaeva, E.Yu. Makeeva, Financial Analysis. Capital Management. Investment Selection, Report Analysis, 10 (2000)

8. Yu.M. Lermontov, The Taxation Optimization: Recommendations on Tax Calculation and Payment, 352 (2008)

9. E.L. Logvinov, A.N. Semenova, Electronic Research and Development Journal Economic Studies and Development, 1, 15 (2017)

10. A.F. Myalkina, T.A. Ovodova, V.M. Tregubova, Social and Economic Phenomena and Processes,10(9), 72 (2014)

11. Z.S. Tuyakova, I.V. Satalkina, International Accounting, 23(413), 19 (2016)

12. The typical Development Methodology of Technical and Industrial Financial Plan of Production Association (Plant) (1979)

13. Davis, G.A., Lund, D., Energy Journal, 39(6), 189 (2018) 